\title{
咽喉頭異常感を主訴とした食道カンジダ症
}

\author{
永野 広海・吉福 孝介・黒野 祐一*

\section{Four Patients with Esophageal Candidosis Presented with Foreign Body Sensation of the Larynx}

\author{
Hiromi Nagano and Kousuke Yoshifuku \\ (Ooshima Prefecture Hospital) \\ Yuichi Kurono \\ (Kagoshima University Graduate School of Medical and Dental Sciences)
}

\begin{abstract}
Esophageal candidosis is not a rare disease. It is caused by Candida albicans, which is normally indigenous in the oral cavity and the large intestine, but becomes pathogenic due to ingestion of antibiotics, steroids and immunosuppressants, complication of malignant tumors, and HIV infection.

We encountered 4 patients who consulted our hospital with a chief complaint of foreign body sensation of the larynx and were diagnosed with esophageal candidosis by upper gastrointestinal endoscopy. The patients were a 79-year-old woman with diabetes as an underlying disease, a 69-year-old man with laryngeal cancer (after radiotherapy), a 54-year-old man with laryngeal cancer (after laryngectomy), and a 46-year-old woman with no underlying disease. The clinical symptoms resolved rapidly within 1 month following oral administration of antifungal agents.
\end{abstract}

Key words : esophageal candidosis, foreign body sensation of the larynx, upper gastrointestinal endoscopy

はじめに

食道カンジダ症は決してまれな疾患ではなく，通常口 腔内や大腸に常在している Candida albicans が, 抗生剂, ステロイド剤, 免疫抑制剤の服用, 悪性腫瘍の合併, HIV 感染などでは病原性を有するようになり発症しやすくな る感染症である. 臨床症状は, 燕下困難, 曣下痛, 胸や けや胸骨後部痛などを訴える. 確定診断は，上部消化管 内視鏡検查による食道の白斑状隆起やチーズ様渗出物の 証明や培養によってなされ，比較的容易である. また抗 真菌剤の内服により臨床症状は速やかに改善するため に，早期の発見と確定診断が必要とされる.

今回われわれは, 咽喉頭異常感を主訴に当科を受診し, 上部消化管内視鏡検查にて臨床的に診断された食道カン
ジダ症の 4 例を経験したので，若干の文献的考察を加え て報告する。

\section{症例}

症例 $1: 79$ 歳, 女性.

主訴：咽頭違和感.

家族歷：特記すべきことなし。

既往歷：糖尿病にて内服治療中である.

現病歴: 2007 年 3 月頃から咽頭違和感を自覚していた が, 症状がしだいに増悪してきたため, 同年 5 月 17 日当 科を受診した。

初診時所見：間接喉頭鏡や喉頭内視鏡検查（図 1）で は，異常所見は認めなかった。 耳, 鼻, 口腔および咽頭 


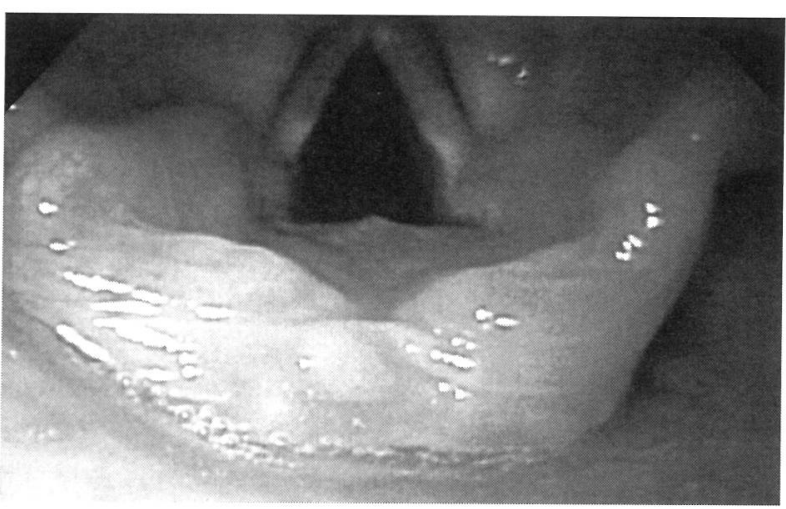

図 1 症例 1 の初䛦時の喉頭内視鏡検查（2007 年 5 月 17 日） 喉頭，下咽頭に異常所見は認めない。

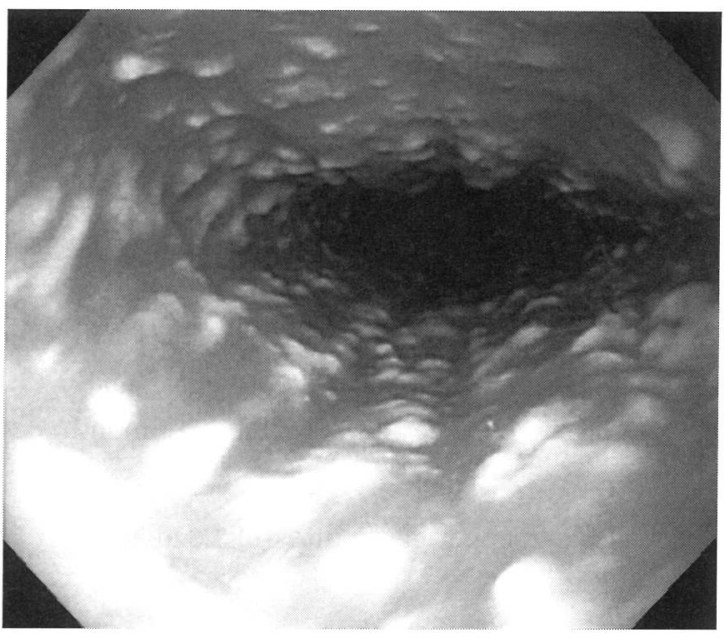

図 2 症例 1 の上部消化管内視鏡検査（2007 年 5 月 17 日） 頸部から胸部食道にかけて全周性に白斑状隆起物の付着 を認める。

粘膜にも異常所見は認めなかった。消化管疾患の精查の ため，同日当科にて上部消化管内視鏡検査を施行した。

検查所見：頸部から胸部食道にかけて全周性に白斑状 隆起物の付着を認めた (図 2). 腫瘍性病変や逆流性食道 炎に伴う粘膜病変は認めなかった。

経過: 以上の検查所見加, 咽頭違和感の原因は食道 カンジダ症によるものと判断し, 同日から抗真菌剤の内 服を開始した. 2 週間程度で症状は消失し， 3 週間で内服 は終了した。 7 月 31 日に治療効果の確認のため, 上部消 化管内視鏡検查を施行したが，カンジダに伴う所見は消 失していた（図 3)。以降症状は訴えていない.

症例 $2: 69$ 歳, 男性.
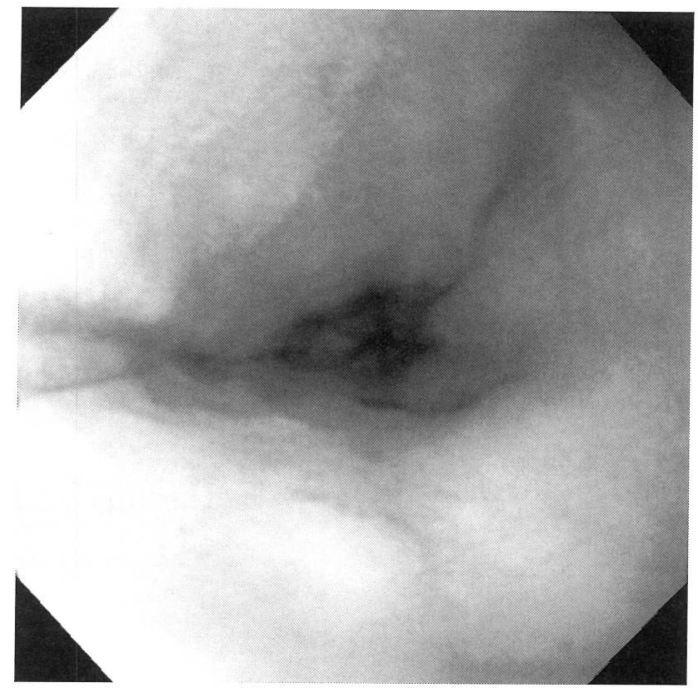

図 3 症例 1 の抗真菌剤による治療後の上部消化管内視鏡検査. (2007 年 7 月 31 日)

白色病変は消失している.

主訴：咽頭違和感.

家族歴：特記すべきことなし。

既往歷：高血圧症にて内服治療中である。2004 年 1 月 喉頭癌（T1a N0 M0）に対して放射線治療（60 Gy）老施 行した。

現病歴と経過：上記の放射線治療以降，咽頭の乾燥感 が継続し，うがい薬にて毎日頻回にうがいをしていた。 2007 年 4 月頃加ら，咽頭の乾燥感とは別に，違和感を自 覚するようになった。同年 6 月 22 日当科を受診した。同 日当科にて上部消化管内視鏡検查を施行し，頸部から胸 部食道にかけて全周性に白斑状隆起物の付着を認加, 食 道カンジダ症と診断した。同日から抗真菌剤の内服を開 始した。 3 週間程度で症状は消失し, 4 週目で内服は終了 した。また頻回のらがいは口腔内の細菌叢に影響を及ぼ す可能性があるため, 使用頻度を減らすように指導した。

症例 $3: 54$ 歳, 男性.

主訴：咽頭違和感と食欲不振。

家族歴：特記すべきことなし。

既往歴：2006 年 8 月に喉頭癌（pT4 N0 M0）に対して 喉頭摘出術を施行した。

現病歴と経過：2007 年 6 月頃加ら, 咽頭違和感と食欲 不振を訴えた。 7 月 5 日当科にて上部消化管内視鏡検查 を施行し，その所見から食道カンジダ症と診断した。抗 真菌剤を 2 週間内服し, 症状は速やかに改善した。 


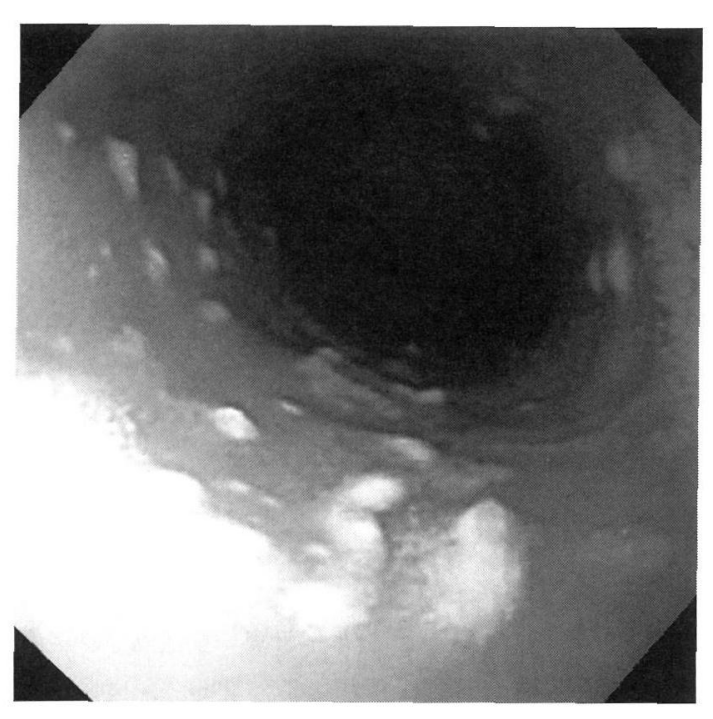

図4 症例 4の初㟝時の上部消化管内視鏡検查 (2007年5月 17 日) 頸部吕ら胸部食道にかけて全周性に白斑状隆起物の付着 を認める。

症例 $4: 46$ 歳, 女性.

主訴：咽頭違和感と食欲不振.

家族歴：特記すべきことなし。

既往歴：特記すべきことなし。

現病歴と経過：2007 年 5 月の始め頃から, 咽頭のひっ かかり感を自覚し，5月 17 日当科を受診し，同日当科に て上部消化管内視鏡検查を施行し，食道カンジダ症と診 断した（図 4)。抗真菌剂を4週間内服し，症状は速や汃 に改善した。

\section{考察}

食道カンジダ症は, 決してまれな疾患ではなく, 通常 口腔内や大腸に常在しているCandida albicans が抗生剂, ステロイド剂, 免疫抑制剤の服用, 悪性腫瘍の合併, HIV 感染などでは病原性を有するようになり発症しやすくな る感染症である。小沢ら ${ }^{11}$ は，上部消化管内視鏡検查を 施行した 7, 083 例を検討し，63 例 (0.89\%) が食道カン ジダ症であり，そのらち 42 例は，明らかな基礎疾患を有 さなかったと報告しており，発症するのは必ずしも免疫 力が低下している症例だけではない。われわれの経験し た 4 症例の中でも, 46 歳の女性では明確な基礎疾患を認 めなかった。

臨床症状は，曣下困難，嚥下痛，胸やけや胸骨後部痛 などを訴える。食道は, 通常耳鼻咽喉科医の診察する領
域に隣接する臟器であり, 近年咽喉頭買常感と逆流性食 道炎との関連性は注目されており2)，当科では，積極的 に上部消化管の精查を行っている. しかし食道カンジダ 症が原因による咽喉頭異常感を訴えて耳鼻咽喉科を受 診したとする報告は，われわれが渉猟しえた範囲では嶋 崎ら 3) が報告した HIV 感染に伴う食道カンジダ症と周東 ら方が報告した点鼻ステロイドが原因と考えた食道カン ジダ症しか見当たらなかった。 また咽喉頭異常感症と食 道カンジダ症を検討した報告も国内外では渉編しえな か⿰た。

2007 年 5 月から 8 月まで 4 力月間に咽喉頭異常感を訴 えて当科を受診し, 耳鼻咽喉科領域に異常所見を認めな かった患者は 162 例であった。 そのうち当科にて上部消 化管内視鏡検查を受けたのは 29 例で, そのうち 4 例が食 道カンジダ症と診断された。

咽喉頭異常感訴え耳鼻咽喉科受診し, 咽喉頭に器 質的疾患を認めなくても，食道疾患を検索する意味で上 部消化管内視鏡検查は必要な検査である。また耳鼻咽喉 科領域において咽喉頭異常感症と診断されたが上部消化 管内視鏡検查を受けていない症例の中に, 食道カンジダ 症を起因とする症例が潜在している可能性があり, 今後 も症例の検討を積み重叔る必要があるのではないかと考 えた.

食道カンジダ症の確定診断には, X 線食道透視造影検 查兮行わ机ることもあるが，上部消化管内視鏡検查が鋭 敏かつ特異性が高く有用である. その所見として, 食道 の点状の白斑状隆起, チーズ様滲出物, 発赤, 浮腫, び らん, 粘膜の脆弱性や内腔狭窄を認め, 診断は容易であ る。また粘膜病変が不明膫な場合は, 渗出物から細菌検 查において Candida albicans を証明することで診断され

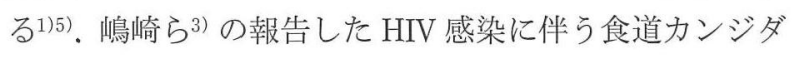
症では, 下咽頭にも白苔の付着を認めたとされるが, 通 常下咽頭粘膜正常である.われわれの経験した 4 症例 でも，下咽頭は正常であり上部消化管内視鏡検查の特徵 的な所見によって臨床的に診断した。

何らかの基礎疾患または自覚症状を有し, 重症化が予 測される場合には経口内服や点滴静注の積極的な治療が 必要である5). 具体的には, ポリエン系抗真菌薬である アムホテリシン B (AMPH-B；ファンギゾン®)，またア ゾール系抗真菌薬のイトラコナゾール (ITCZ; イトリ ゾール®) を $2 \sim 4$ 週間程度の期間内服する. AMPH-B は, ITCZに比べて副作用（細胞毒性）などの安全性は劣 
るとされるが，抗真菌スペクトラムは広いとされてい る6).

軽症例や自覚症状がなく偶然発見されるような症例で は，自然に軽快することもあるが，重症例では診断や治 療が遅れた場合, カンジダ敗血症へ移行し重症化する可 能性もあり注意が必要である5).

以上から咽喉頭異常感を訴える症例は, 下咽頭癌, 頸 部食道癌, 喉頭癌を見逃さないことも耳鼻咽喉科医とし ては当然必要なことである7) が，また本症も念頭に置く ことが必要である．また診断をするうえで，上部消化管 内視鏡検査は必須の検査である.

$$
\text { まとめ }
$$

1. 咽喉頭異常感を主訴に当科を受診した食道カンジ ダ症の 4 例を報告した。

2. 食道カンジダ症はまれな疾患ではなく, また適切に 治療すると臨床症状は速やかに軽快するため, 咽喉頭異 常感を訴える症例では本症を念頭に置くことが必要であ る.

3. 4 症例とも抗真菌剤の内服で, 速やかに臨床症状が 改善した。

4. 適切な診断と治療を行うためには, 上部消化管内視
鏡検査は必須である.

\section{参考文献}

1）小沢壮治, 大森 泰, 幕内博康: カンジダ食道炎 63 例の検 討. Prog Dig Endosc $30: 87 \sim 90,1987$.

2) 福岩達哉: GERD と耳鼻咽喉科疾患. Pharma Med $25: 78$ $\sim 80,2007$.

3）嶋崎孝嗣, 吉田義一: 咽喉頭異常感症として危うく見過ご されそうになった AIDS の 1 例. 耳鼻と臨 $43: 171 \sim 177$, 1997.

4）周東 寛, 野口 久, 西片 光, 他 : 睡眠前の点鼻ステロ イド剤長期投与が原因と思われた食道カンジダ症の 1 例. アレルギー $56: 714 \sim 720 ， 2007$.

5）長野正裕：内視鏡分類 日本と世界 食道カンジダ症の内 視鏡分類. 消内視鏡 $12: 26 \sim 27,2000$.

6）北村正樹：深在性真菌症治療薬一イトラコナゾールの新剂 形一. 耳鼻展望 $50: 61 \sim 64,2007$.

7) 黒野祐一：咽喉頭異常感症. 今日の治療指針 (山口 徹編). 1024 頁, 医学書院, 東京, 2004.

原稿受付：平成19年 9 月 14 日

原稿採択：平成19年10月24日

別刷請求先 : 永野広海

干894-0015 奄美市名瀬真名津町18-1

鹿児島県立大島病院耳鼻咽喉科 